\title{
Proofs of Existence (Dowody na istnienie)
}

\author{
Author: Hanna Krall
}

First Published: 1995

Translations: German (Existenzbeweise, 1996); Italian (Il dibbuk e altre storie, 1997); Swedish (Existensbevi, 1997); French (Preuves d'existence, 1998); Slovak (Dôkazy jestvovania, 1998); Hebrew (Hokhatot le-kiyum, 1999); English (Proofs of Existence: The Dybbuk; The Chair, A Fox, The Tree; Salvation, Hamlet, A Decision. In: The Woman from Hamburg and Other True Stories, 2005); Czech (Důkazy pro..., 2011).

Theatre Adaptation: Dybuk. Między dwoma światami (Dybbuk. Between Two Worlds), director Krzysztof Warlikowski, screenplay based on works written by Hanna Krall and Szymon An-Ski, premiered the 2003 in Teatr Rozmaitości (Warsaw).

About the Author: Hanna Krall (between 1935 and 1937) is a writer and journalist of Jewish origin. Her works revolve around the Shoah and the fate of Polish Jews. She has a degree in journalism from the Warsaw University. In 1955, she started to work as an editor for Życie Warszawy daily; later she also cooperated with Polityka weekly and "Tor” film studio. She made a name for herself for an interview with Marek Edelman, one of the leaders of the Warsaw Ghetto Uprising, entitled Shielding the Flame (1977).

Further Important Publications: Zdążý przed Panem Bogiem (1977, Shielding the Flame; reportage with the elements of documentary novel and interview); Sublokatorka (1985, $\rightarrow$ The Subtenant; novel); Hipnoza (1989, Hipnosis; reportages); Taniec na cudzym weselu (1993, Dancing at Someone Else's Wedding; documentary stories); Tam już nie ma żadnej rzeki (1998, There Is No River There Anymore; reportages); To ty jesteś Daniel (2001, So You Are Daniel; documentary stories); Wyjątkowo dhuga linia (2004, An Exceptionally Long Line; novel); Król kier znów na wylocie (2006, Chasing the King of Hearts, novel).

\section{Content and Interpretation}

Nine journalistic stories collected in the book Proofs of Existence are devoted to the problem of Jewish identity and the compulsion for recovering, finding, or confirming it. Other more common themes can be found throughout the collection: a Jewish childhood marked by the experience of the Holocaust, for instance. These are ethical dramas, revolving around unimaginable choices, and the moral "burdens" so difficult to bear after the war is over.

The protagonists of Krall's reportages often experience some combination of postwar amnesia, especially those who are Holocaust witnesses and survivors (A Regret), and difficulties long into the postwar period remembering their roots (Amnesia).

๖ Open Access. () 2021 Urszula Kowalska-Nadolna, published by De Gruyter. (c) BY-NC-ND This work is licensed under a Creative Commons Attribution-NonCommercial-NoDerivatives 4.0 License. https://doi.org/10.1515/9783110671056-084 
As Adam Krzemiński writes, Hanna Krall "holds in her arms an infinite number of shadows" (1993, p. 20). The imperative to record the memory of certain people and their lives leads the author in one episode to a street in Leżajsk that "did not want to hear any questions” (A Regret, Krall, 2019, p. 557). Krall's listing of addresses and names that are no longer present ("They do not have gravestones, let them be in a book") has provoked anxiety and resentment among today's residents of former Jewish homes.

The subject of The Dybbuk, which opens the book and is probably the best known text in the collection, is Adam S., an American scientist born in France after the war. He is visited (or perhaps possessed) by the spirit of his younger stepbrother, who probably died in the Warsaw Ghetto and who has come to remind him of his Polish-Jewish roots (in the Jewish tradition, a dybbuk is the soul of a dead acquaintance who lives on in a living man). The protagonist is forced by the dybbuk to carry the burden of his family history, but at the same time, he does not allow his stepbrother to leave.

Krall's tales commemorate very different people and cases - Eastern European Jews, Jewish children who went missing (or were secretly hidden), a woman who avenges her husband many years after he was murdered by roommates, the love story of Mrs Miecia and Mr Waldemar against the backdrop of the war, full of betrayal and romance, and a silver-fox fur bought as an apology for a marital indiscretion. Some stories deal with Jews who died in anonymity, whose memory Krall means to save by writing down their names. Other stories deal with living characters - the famous pianist Andrzej Czajkowski, for example, who spent the war in the wardrobe and then "had to prove that he deserved to live" (Hamlet; Krall, 2019, p. 619). Catching "shreds" or "crumbs" of this or that fate becomes a method for preserving the memory of those who "had no chance to reach old age" (Kot, 2000, p. 90), and of those who were compelled to live a double life in the postwar period, between their Jewish and non-Jewish identity. Yet these fragments of biographies, combined in unexpected ways, speak to something universal, the missing pieces of a jigsaw puzzle that is the fate of 20th-century Jews.

Krall's protagonists in Proofs of Existence lead lives marked by fortune and absurdity, by a fate that is difficult to control, and by no-win situations. The events that are most decisive are also the most illogical - a characteristic that on the other hand seems to confirm the existence of some force majeure or act of God - or, as Hanna Krall prefers, the Great Screenwriter.

However, the title also refers to the survivors themselves and to a recurring question regarding the purpose and reason for their survival. Attempts to reconstruct individual stories lead to the discovery of new traces of identity belonging at times to other survivors, at other times to those who died. According to Wiesław Kot, "fate is complicated by the fact that the war biographies of Jews are perpetually tinged with a sense of the improbable" (p. 102). The absurd becomes a full-fledged fragment of historical truth, as for example in the story of Andzia and her daughter Lina, who are replaced by unknown women on their way to the Umschlagplatz (Salvation). 


\section{Main Topics and Problems}

Proofs of Existence raises an issue that concerns nearly all of Krall's writing: a certain incompatibility of the term "reportage" in relation to her work. Literary techniques close to reportage can be found elsewhere - in Borowski's $\rightarrow$ A Farewell to Maria, Nałkowska's $\rightarrow$ Medallions, and Rudnicki's cycle Age of the Ovens ( $\rightarrow$ The Escape from Yasnaya Polyana, Shakespeare), for example. In the case of Proofs of Existence, however, it seems reasonable to create a new category, after Ryszard Krynicki's notion of "metaphysical reportage" (Krall herself once claimed that every reportage "should include a metaphysical surplus"). Yet another term was suggested by Michał Cichy, who describes Proofs of Existence as "documentary tales". As he claims "the poetics of fairy tales are particularly well suited to the story of the Holocaust [...]. A fairy tale always has one hero, so we can identify with him... Fairy tales may speak to the existence of terrible things, but they are also optimistic, in the sense that they allow you to finally overcome terror and regain trust in the world" (Cichy, 1999, p. 16).

Paradoxically, thanks to Krall's "compaction of the text" - a term coined by the author herself to describe the reduction of a literary text to its subject matter - these reportages acquire the character of literature, constituting parabolic images of human existence. Krall herself, as usual, remains in the shadow of the memories of her heroes, but it is also not difficult to see autobiographical threads in several stories.

Like two other collections by Krall from the 1990s - Dancing at Someone Else's Wedding (1993) and There Is No River There Anymore (1998) - Proofs of Existence advances a belief in the existence of an "indelible" Jewish identity, to which many of Krall's protagonists return again and again, until it becomes something of an obsession or compulsion. By contrast, one also finds stories where it is precisely a hidden or displaced identity that is at stake, as in Amnesia, about a doctor in the postwar period who expurgates uncomfortable facts from her biography - her Jewish origin and mother in Israel - in order to save her career.

Some stories deal with identity recently found, others with an identity not yet found. Małgorzata, for example, works in the archive of the Jewish Historical Institute, helping to rewrite the life stories of Jewish children of Polish parents who, after many years, are looking for the truth of their origins (Amnesia). In still other stories, identity is the object of desire - the case of Peter Schok, for example, a homosexual dying of AIDS who adds Jewish elements to his non-Jewish biography (A Decision). These individual narratives come together in a multi-voiced and diverse memory dialogue, with a separate story behind each existence (Kot, 2000, p. 102). In Krall's reportages, however, there is a metaphysical, supernatural element behind which stands - or through which shines - the Great Screenwriter: "The work of a reporter taught me that logical stories, without puzzles and gaps in which everything is understandable, can be untrue. And the opposite: things that could not be explained are very often real" (Krall, 2019, p. 583). 


\section{Cited Works}

Cichy, M. (1999). Baśnie dokumentalne Hanny Krall. Gazeta Wyborcza, (23), pp. 16-17. Kot, W. (2000). Hanna Krall. Poznań: Dom Wydawniczy Rebis. Krall, H. (2019). Dowody na istnienie. In: H. Krall, Fantom bólu. Reportaże wszystkie. Kraków: Wydawnictwo Literackie, pp. 541-644. Krzemiński, A. (1993). Nam samym ta pamięć potrzebna. Polityka, (16), p. 20.

\section{Further References}

Antczak, J. (2015). Reporterka. Rozmowy z Hanna Krall. Warszawa: Agora. Bode-Jarsumbeck, D. (2014). Die literarischen Reportagen Hanna Kralls. Gedächtnis an die ostjüdische Lebenswelt und die Shoah. Wiesbaden: Harrassowitz Verlag. Bratkowski, P. (1998). Tam wciąż płynie rzeka. Gazeta Wyborcza, (221), p. 2. Jeziorska-Haładyj, J. (2010). Zawartość zmyślonej, żółtej walizki. O prozie Hanny Krall. Pamiętnik Literacki, 101(4), pp. 37-60. Mąka-Malatyńska, K. (2006). Krall i filmowcy. Poznań: Wydawnictwo Poznańskie. Pluwak, A. (2015). Ambiguous Endeavours: the Evolution of the Melodramatic Mode in Polish Holocaust Narratives from Hanna Krall to The Aftermath. Lund: Centre for Languages and Literature, Lund University. Tochman, W., (2015). Krall. Rozmowa. Warszawa: Dowody na Istnienie.

UKN 